\title{
Effects of Two Cutting Heights on Yields of Five Tropical Grasses ${ }^{1}$
}

\author{
Rubén Caro-Costas and José Vicente-Chandler²
}

\section{INTRODUCTION}

The effects of fertilization, frequency of cutting, grazing versus cutting management, and of season of the year on yields and composition of the major grasses of Puerto Rico have been studied in considerable detail $(2,3,4,5)^{3}$. However, the authors have found little quantitative data in the literature on the effect of cutting heights on productivity of these grasses. Caro-Costas and Vicente-Chandler (1) found that Napier grass cut to a height of 2 inches from the ground yielded more than when cut to a height of about 10 inches. Watkins and Lewy (6) reported that highest yields of Napier and molasses grass were obtained by cutting to a height of 6 to 8 inches, and of Guinea grass by cutting to a 12-inch height, but did not present data to substantiate these conclusions.

The purpose of the present study was to determine the effect of two cutting heights on the productivity of well-fertilized Napier grass (Penniseium purpureum), Guinea grass (Panicum maximum), Pangola grass (Digitaria decumbens), molasses grass (Melinis minutiflora), and Para grass (Panicum purpurascens) mixed with some Carib grass (Eriochloa polystachya), under typical conditions in the humid mountains of Puerto Rico.

\section{METHODS AND PROCEDURE}

The experiment was carried out at Orocovis, which has a mean annual temperature of about $75^{\circ} \mathrm{F}$, and a seasonal variation of less than $10^{\circ} \mathrm{F}$. Annual rainfall was 77.8 and $\mathbf{6 0 . 0}$ inches for the first and second years of experimentation, respectively. The soil was Catalina clay, a deep, red, acid lathosol, on 30-percent slopes. The surface 6 inches had 4.5 percent of organic matter; a pH of 5.3; 16.5 m.e. of exchange capacity, and 10.4 m.e. of exchangeable bases per $100 \mathrm{gm}$. of soil; and a volume weight of 0.98 with 11 percent of the pores drained at a tension of $60 \mathrm{~cm}$. of water.

1 This report covers work carried out cooperatively between the Soil and Water Conservation Research Division, Agricultural Research Service, USDA, and the Agricultural Experiment Station, University of Puerto Rico, Río Piedras, P.R.

2 Agronomist, cooperative between USDA and the Puerto Rico Station, and Project Supervisor, Soil and Water Conservation Research Division, Agricultural Research Service, USDA, respectively.

${ }^{3}$ It alic numbers in parentheses refer to literature cited, p. 49. 


\section{TREATMENTS}

Grasses were cut: 1 , Close to the ground (0-3 inches) and 2, high (7-10 inches from the gfound).

Treatments were replicated five times for each grass, using plots $10 \times 30$ feet in size. All plots were limed to about $\mathrm{pH} 6.0$ and received 3,000 pounds of 14-4-10 fertilizer per acre yearly in six equal applications.

TABLE 1.-The effect of two culting heights on annual yields and protein content of 5 well-fertilized tropical grasses growing in the humid mountains of Puerto Rico, and harvested every 2 months over a 2 -year period, 1958-59

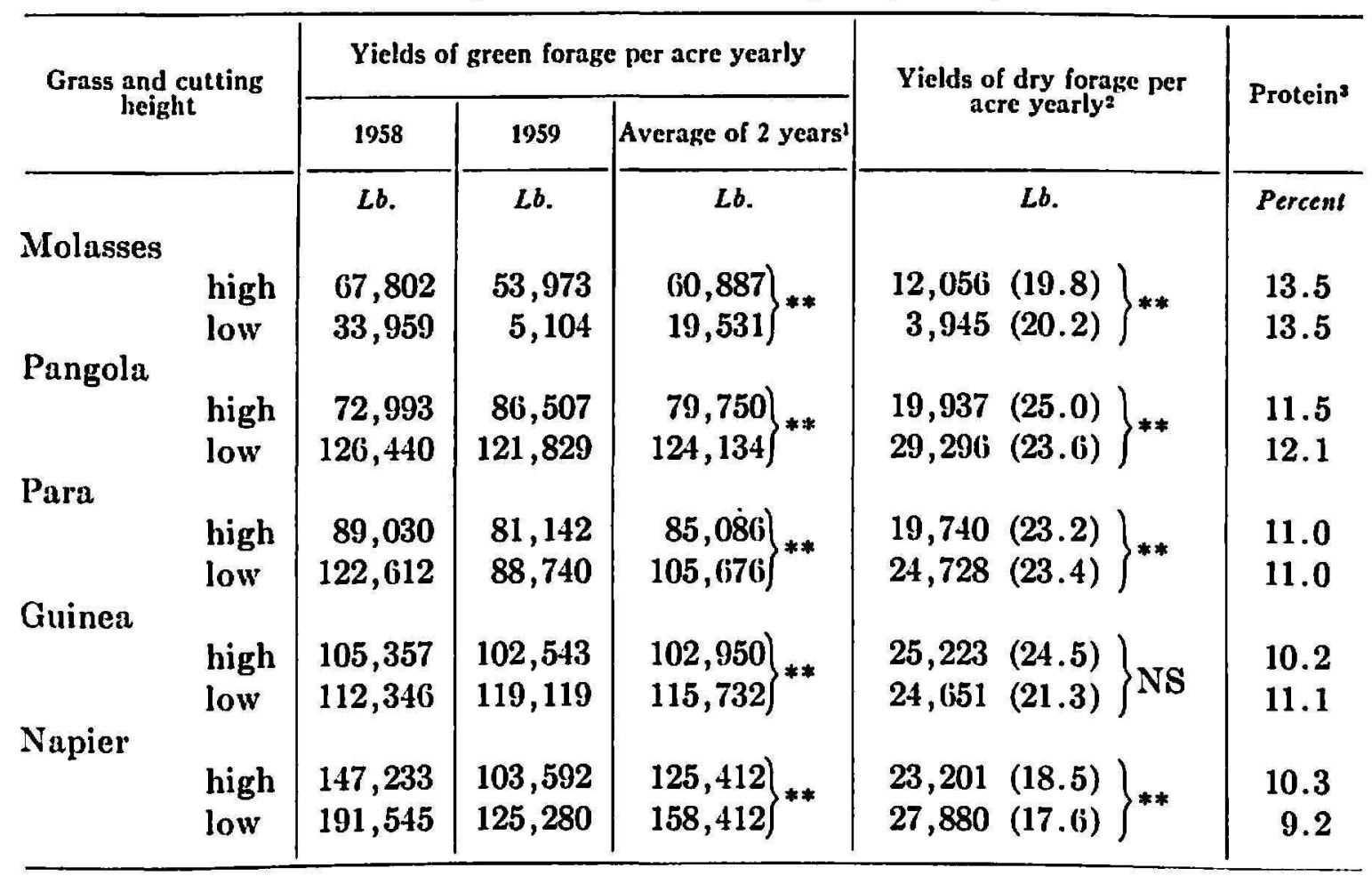

1 Asterisks indicate differences are statistically highly significant (0.01 level).

2 Numbers in parentheses indicate percentage of dry matter.

${ }^{3}$ On a dry-weight basis.

The forage in all plots was harvested every 2 months by cutting to the prescribed height, and was weighed. Samples were taken from each plot once a year and their dry-matter and protein contents determined.

The experiment ran a full 2 years.

\section{RESULTS AND DISCUSSION}

Results are summarized in table 1 .

Yields of molasses grass were severely reduced by close cutting. By the end of the first year this grass had almost diappeared from the plots cut close to the ground. 
On the other hand, much higher yields of Napier, Para, and Pangola grass were obtained with close cutting. Yields of green Napier grass were increased 27 percent, of Para grass 25 percent, and of oPangola grass 56 percent by cutting close to the ground. Higher yields were obtained with low cutting at all seasons of the year with these grasses.

Cutting height had no apparent effect on yields of dry Guinea grass. However, high cutting seems more desirable since it resulted in a better stand, faster recovery after harvesting, and less weed growth. Slightly more total green forage was produced with low cutting, but the reverse occurred during some periods, probably due to seasonal effects on bud differentiation.

Height of cutting had no apparent effect on protein content of the grasses.

The sharp differences in yields caused by varying cutting heights are striking and show the importance of managing each grass in accordance with its requirements. For example, if molasses and Pangola grasses were compared with high cutting they would produce similar yields; if with low cutting molasses grass would yield little and eventually disappear, while if both grasses were cut at the best height for the species (i.e. close cutting with Pangola and high cutting with molasses) Pangola would yield about twice as much forage as molasses grass.

\section{SUMMARY}

The effect on the productivity and protein contents of well-fertilized Napier, Para, Guinea, Pangola, and molasses grasses harvested every 60 days for 2 years, of cutting close to the ground ( $0-3$ inch) or to a 7-10 inch height, was determined under typical conditions in the humid mountains of Puerto Rico.

Yields of molasses grass were severely reduced by close cutting and the grass eventually disappeared from plots with this treatment. On the other hand, yields of Napier, Para, and Pangola grasses were increased 27, 25, and 56 percent, respectively, by low cutting. Although yields of Guinea grass were not strongly affected by cutting height, high cutting resulted in a better stand, faster recovery after harvesting, and less growth of weeds.

\section{RESUMEN}

Se estudió el efecto en el rendimiento de yerbas Napier, Pará, Guinea, Pangola y melao, de cortarlas a una altura de $0-3$ y de $7-10$ pulgadas del suelo cada 60 días durante 2 años.

Con corte bajo se redujo grandemente el rendimiento de la yerba melao. Sin embargo, los rendimientos de las yerbas Napier, Para y Pangola fueron marcadamente más altos con corte bajo. Aunque la altura de corte no 
afectó grandemente el rendimiento de la yerba Guinea, con corte alto se mantuvo más vigorosa, recobró más rapidamente después del corte, y crecieron menos malas yerbas.

\section{LITERATURE CITED}

1. Caro-Costas, R., and Vicente-Chandler, J., Comparative productivity of Merker grass and of a Kudzu-Merker grass mixture as affected by season and cutting height, J. Agr. Univ. P.R. 40 144-51, 1956.

2. Caro-Costas, R., Vicente-Chandler, J., and Figarella, J., The yields and composition of five grasses growing in the humid mountains of Puerto Rico, as affected by nitrogen fertilization, season, and harvest procedure, J. Agr. Univ. P.R. 40 107-20, 1960.

3. Little, S., Vicente-Chandler, J., and Abruña, F., Yield and protein content of irrigated Napier grass, Guinea grass, and Pangola grass, as affected by nitrogen fertilization, Agron. J. 51 111-3, 1959.

4. Rodriguez, J., Effect of nitrogen applications on the yields and composition of forage crops, J. Agr. Univ. P.R., 33 98-117, 1949.

5. Vicente-Chandler, J., Silva, S., and Figarella, J., The effect of nitrogen fertilization and frequency of cutting on the yield and composition of three tropical grasses, Agron. J. 51 202-6, 1959.

6. Watkins, J. M., and Lewy-van Severin, M., Effect of frequency and height of cutting on the yield, stand and protein content of some forages in El Salvador, Agron. J. 43 291-6, 1951. 